\title{
Ṣūfism and the Gurdjieff 'Work': A Contested Relationship
}

\author{
Carole M. Cusack
}

\section{Introduction}

The origins of 'the Work', the system taught by the Greek-Armenian esoteric spiritual teacher, George Ivanovich Gurdjieff (c. 1866-1949) remain obscure, and its sources have been sought in a range of religious traditions, most commonly Buddhism, Christianity, and Șūfism. ${ }^{1}$ This chapter interrogates the claim that Gurdjieff's teaching is broadly derived from Islamic sources, in particular central Asian Șūfism. Gurdjieff spoke of his system as "esoteric Christianity," and his cosmology owes a debt to neo-Platonism, in particular the works of Iamblichus (Azize 2010). However, his pupil John Godolphin Bennett (18971974) believed that Șufism was the ultimate source of Gurdjieff's teaching. In this chapter Șūfi influence is identified in four areas of the Work.

First, Gurdjieff's travels in search of wisdom, chronicled in a fictionalised form in Meetings with Remarkable Men (1963), seemingly led him to Șūfi monasteries in Central Asia, where he learned the meditative techniques of "self-remembering" and the "Movements" (Hunt 2003). Gurdjieff's magnum opus, Beelzebub's Tales To His Grandson (1950) also features Șūfi characters and teaching stories. Second, the sacred dances or Movements that Gurdjieff taught have been presumed to originate in dervish dances (Barber 1986). Third, his pupil John Godolphin Bennett (1897-1974) identified Gurdjieff's distinctive persona and teaching method, involving insults and "shocks," as deriving from the Șūfi malamatiyyah or "way of blame" (Bennett 1973). Bennett's involvement with soi-disant Șūfi master Idries Shah (1924-1996) and with Indonesian new religion Subud (founded by Muhammad Subuh Sumohadiwidjojo, 1901-1987), itself influenced by (Javanese) Șūfism, is discussed (Geels 1997), as is the Bennett lineage's links with contemporary Ṣufism. Fourth and finally,

1 I am grateful to my research assistants Drs Johanna Petsche and Venetia Robertson, and Mr Ray Radford, who all worked on this project. Thanks are due to Professor Mark Sedgwick (Aarhus University), who has generously shared his research on Gurdjieff and Șufism with me. 
Gurdjieff's famous nine-sided figure, the Enneagram, has been dubiously connected to Șūfism and used by post-Gurdjieffians and neo-Ṣūfis, including psychologist and spiritual teacher A. Hameed Ali (b. 1944), better known as A.H. Almaas (Almaas 1998) and Oscar Ichazo (Lilly and Hart 1975: 331).

It is concluded that it is valid to identify Șūfi influences within the Gurdjieff 'Work,' with varying degrees of prominence depending on the teaching lineage. However, it is inaccurate to state that Gurdjieff was a Șūfi teacher, or to claim that the Work is a modern Western form of Șūfism (and thus an 'Islamic' new religious movement). In the twenty-first century the Fourth Way and Șūfism are associated through processes of spiritual eclecticism and bricolage, and internet and popular cultural media.

\section{Ṣūfism in Gurdjieff's Life and Writings}

George Ivanovich Gurdjieff was born c. 1866 "in Alexandropol [now Gyumri, Armenia], on the Russian side of the Russo-Turkish frontier, his father a Cappadocian Greek carpenter and bardic poet (ashokh), and his mother an illiterate Armenian" (Moore 1994a: 19o). When Gurdjieff was a child the family moved to Kars, where he became a chorister at the Kars Military Cathedral school. He emerged as a spiritual teacher in 1912 in Moscow, married Julia Ostrowska in St Petersburg in the same year, and attracted pupils, the most important of whom was mathematician and esotericist Pyotr Demianovich Ouspensky (1878-1947). In 1917 Gurdjieff and his pupils left Russia, escaping the Revolution. From 1917-1922 they were based chronologically at Essentuki, Tblisi, Constantinople, Berlin, and finally Paris, where Gurdjieff founded the Institute for the Harmonious Development of Man at the Prieuré des Basses Loges at Fontainebleau-Avon for a second time (Rawlinson 1997). In 1924 he had a near-fatal car crash, disbanded the Institute, and moved to a flat in central Paris. Gurdjieff then focused on writing his three major works, assisted by his secretary Olga de Hartmann and translator Alfred R. Orage. From 1922 until his death in 1949, apart from some travels, Gurdjieff remained in France (Rawlinson 1997: 283).

Until P.D. Ouspensky met Gurdjieff and began to document his teachings there was no external testimony concerning Gurdjieff's life. Ouspensky separated from Gurdjieff in 1924, by which time the journalistic chronicling of Gurdjieff's life had become established. Ouspensky taught the Gurdjieff system until his death in 1947 and published the earliest and most systematic version of the teaching, In Search of the Miraculous (1949). Mark Sedgwick has argued he made a greater contribution to the Work than is generally 
acknowledged, and that "much of what is known as the Gurdjieff teaching is actually Ouspensky's teaching" (Sedgwick 2019: 132). Gurdjieff's writings, Beelzebub's Tales to his Grandson (1950), Meetings with Remarkable Men (1963), and Life is Real Only Then, When 'I Am' (1974), were published posthumously (Moore 1991). Gurdjieff's quasi-autobiographical Meetings presents him as a seeker of wisdom, one desirous to unite religious, esoteric and scientific knowledge. Meetings records the quest by Gurdjieff and his friends, a group calling themselves the 'Seekers of Truth'. They included: Abram Yelov, an Assyrian Christian; trainee Orthodox priest turned engineer Sarkis Pogossian; the pasha's son Ekim Bey; archaeologist Professor Skridlov; one 'remarkable woman' Vitvitskaia; and Prince Yuri Lubovedsky, the principal spiritual guide in Gurdjieff's book. The Seekers of Truth allegedly travelled in search of ancient wisdom in the 188 os and 189 os. They went on an expedition to the Gobi Desert, visited Egypt (which Gurdjieff linked to Atlantis), experimented with music and vibrations, met wandering holy men in Central Asia, and Gurdjieff himself finally found the monastery of the fabled Sarmoung Brotherhood, where he reunited with Prince Lubovedsky and learned the sacred dances, or Movements (Moore 1991: 31-32).

There has been much speculation about the sources of Gurdjieff's teachings, and how reliable the account of his early years given in Meetings is. The Fourth Way or 'Work', as Gurdjieff's teaching is called, has been described as an amalgam of esoteric Christianity, Șūism, Tibetan Buddhism, Western occult traditions, and Hindu ideas. Gurdjieff himself never acknowledged a master. Certain Gurdjieff pupils, like J.G. Bennett, thought that Gurdjieff's travels were based in reality. He believed that Gurdjieff had lived with Essenes and at the Christian monastery of Mount Athos, and had visited Ethiopia where he acquired knowledge of Coptic Christianity. Bennett also accepted that Gurdjieff spent time in Egypt, Babylon, Afghanistan, and Tibet, and was initiated into a Șüfi order in Central Asia. From the early 195os he travelled extensively in the Islamic world and "clearly sought out the sources of Gurdjieff's teachings from the Muslims that he met" (Pittman 2012: 123). Yet during Gurdjieff's life the orientation to Süfism was not apparent to many of his key pupils, the most prominent of whom was Jeanne de Salzmann (1889-1990), his nominated successor. She established the Gurdjieff Foundation (with branches in London, New York, Paris, London, and Caracas), the official teaching and institutional lineage of the Work. The changes which de Salzmann made late in her life were criticized sharply by James Moore; he charged that she introduced Hindustyle meditation aimed at awakening the Kundalini, when Gurdjieff dismissed "Indian religiosity in general ('a bordel for Truth') and Kundalini in particular" (Moore 1994b: 13). 
The first account of Gurdjieff's teaching to be published was Ouspensky's Search, and when the two met in 1915 Ouspensky was known as the author of Tertium Organum (1912), in which he spoke of Șūfism as "a philosophical school of a very high idealistic character, which struggled against materialism as well as against narrow fanaticism and the literal understanding of the Koran" (Ouspensky 1981 [1912]: 250). In Search Ouspensky wrote of his years as Gurdjieff's pupil (he left Gurdjieff in 1924 though he continued to teach Gurdjieff's ideas to his students). He noted Gurdjieff's vagueness regarding the sources of his teachings:

[a]bout schools and where he had found the knowledge he undoubtedly possessed he spoke very little and always superficially. He mentioned Tibetan monasteries, the Chitral, Mount Athos, Sufi schools in Persia, in Bokhara, and eastern Turkestan; he mentioned dervishes of various orders; but all of them in a very indefinite way.

OUSPENSKY 2001 [1949]: 36

When in Istanbul en route to Europe, Ouspensky, Bennett and others visited the Mevlevi tekke with Gurdjieff, and drew parallels between Șūfi exercises and what he had taught them. Ouspensky recalled Gurdjieff saying that "the whirling of the Mehlevi [sic] dervishes was an exercise for the brain based upon counting, like the exercises he had shown us in Essentuki" (Ouspensky 2001: 383). Bennett was convinced that the Șüfi practice of $z i k r$ or $d h i k r$, remembrance of the names of God (Allāh) was the same as Gurdjieff's selfremembering, despite the obvious distinction that one practice was focused on God and the other on the self (Brenner 1972: 646). Bennett also argued that the distinction between (false) personality and (true) essence was of Sunfi origin, and the Study House at the Prieuré reminded him "of the Sema Hanes of the Dervish communities outside the walls of Constantinople" (Bennett 1973: 152).

It is certainly true that Gurdjieff crafted an image that was 'Eastern'; the Study House (an aircraft hangar that was used for Movements) was hung with Persian carpets, and the Turkish bath in which Gurdjieff joked with the men of the Prieuré was also exotic in 1920s Paris. Bennett also saw the "Stop Exercise," in which pupils at Gurdjieff's command ceased moving and froze, as a Șūi practice (Bennett 1973: 227). His conviction that Gurdjieff had studied with the Naqshbandī Ṣūfi order in Bukhara was supported by the fact that the Șüfi characters in Meetings (Bogga Eddin) and Beelzebub's Tales (Hadji-Asvatz-Troov), were both associated with Bukhara. He said of Gurdjieff: 
He put on a mask that would tend to put people off, rather than draw them towards him. Now this method ... the Way of Malamat, or the method of blame - was highly esteemed in old times among the Sufis, who regarded the sheikhs ... who went by the Way of Blame, as particularly eminent in spirituality.

quoted in PITTMAN 2012: 139

Other evidence for Gurdjieff's identification with Șüfism is found in the 'sacred dances' or Movements, and the music he composed with Thomas de Hartmann, both that to accompany the Movements, and piano music that is of three types, "Asian and Eastern Folk Music, Sayyid and Dervish Music, and Hymns" (Petsche 2015: 112). It is to these two teaching tools, dance and music, that we now turn.

The Movements were unveiled by Gurdjieff in 1919 in Tiflis (Tblisi), the site of the first foundation of the Institute for the Harmonious Development of Man, and of the first public Movements demonstration. Yet sacred dances were a teaching method from the start. In "Glimpses of The Truth" (1914), a text that was likely designed to attract students, a seeker asked Gurdjieff about The Struggle of the Magicians, a ballet that he had advertised in 1914. He responded:

in the rhythm of certain dances, in the precise movements and combinations of the dancers, certain laws are vividly recalled. Such dances are called sacred. During my journeys in the East, I often saw dances of this kind executed during the performance of sacred rotes in some of the ancient temples. These ceremonies are inaccessible and unknown to Europeans. Some of these dances are reproduced in The Struggle of the Magicians.

GURDJIEFF 1984 [1973]: 31

The ballet was never performed but is evidence for Gurdjieff's use of dance as a teaching method very early on. Ouspensky notes exercises that were done on a large drawing of the Enneagram (discussed below) on the floor, with students on the numbers from 1 to 9 and moving "in the direction of the numbers of the period in a very interesting movement, turning around one another at the points of meeting" (Ouspensky 20o1: 294-295). Ouspensky did not link 
the symbol to Șūism as later commentators have but considered it particular to Gurdjieff.

The origin of the Movements has been speculated to be the monastery of the obscure 'Sarmoung Brotherhood', although, as Sedgwick has noted, there is no evidence that the Sarmoung Brotherhood existed, and in the Work tradition it functions as a source of authority, like "[Madame Helena Petrovna] Blavatsky's mythical Mahatmas" (Sedgwick 2010: 176). More probably, the Movements reflect a blend of Eastern and Western dance forms, including Ṣufi dervish dances, Anthroposophical Eurythmy, and Dalcroze Eurhythmics (Wellbeloved 2005 [1003]: 45). Jeanne de Salzmann's Dalcroze class were the first Movements students, and it is probably significant that Gurdjieff did not teach Movements prior to Jeanne and her husband Alexandre becoming his pupils. Yet he taught Movements in an expert, rather than an amateur or spontaneous, fashion, which suggests that body-based disciplines were of long-standing interest to him (Cusack 2017). It was at the Sarmoung monastery that Gurdjieff allegedly saw the doll-like machine consisting "of a vertical column fitted with seven movable arms, each attached by seven universal joints. Like a written alphabet, the machine was capable of transmitting an infinite number of sign combinations" (Gordon 1978: 38). This is supposed to have demonstrated the particular postures of the Movements, which often involve complicated and counterintuitive actions of different body parts, such as the head, arms, and legs. This exotic source has never been substantiated, and it seems more likely that, as Gurdjieff noted, when he was young he had "practised mostly Yoga and the gymnastics of the 'Swede Mueller"' (van Dullemen 2014: 215).

Gurdjieff taught that humans are "three-brained beings," who must align their intellectual, emotional and sensory selves into a single self via the development of a finer (or kesdjan), body. His teachings are called the 'Fourth Way', because of the three ways that he connects to the three centres of being. The way of the fakir (Șüfi ascetic) Gurdjieff connects to the body and the sensory centre; the way of the monk (Christian ascetic) he links to the emotional centre; and the way of the yogi (Hindu ascetic) he aligns with the intellectual centre (Cusack 2017:104). All these paths are fragmentary, as they "are all imbalanced because each centre is only aware of part of what we are ... So in effect, there are two kinds of imbalance ... individual neurosis (derived from the fact that centres try to do the work that is proper to one of the others) and 'spiritual lopsidedness' (derived from the fact that no centre can reveal the whole nature of man)" (Rawlinson 1997: 288).

For Gurdjieff the purpose of life is the development of a kesdjan body through work and "conscious suffering." Humans, for Gurdjieff, are essentially 
machines who pass through life asleep. There are four states of consciousness; sleep, waking consciousness (nearly the same as sleep), self-remembering, and objective consciousness, the attainment of which is linked to the development of the kesdjan (astral or higher-being) body. This is a type of soul or immortal element that survives physical death; those without souls become food for the Moon when they die. The Movements are the most important bodily activity undertaken in the Work, and cultivate the physical centre, while the piano music "cultivate(s) the emotional centre," and Beelzebub's Tales cultivates the intellectual centre (Petsche 2015: 182). The transformative nature of the Movements is recognized by Joseph Azize, who notes "there are inner attitudes, which at a certain stage become even more crucial than the corporeal dimension" (Azize 2012: 297).

The script of The Struggle of the Magicians tells of dances taught by the White Magician to his students, including the heroine, the beautiful and modest Zeinab. The description is clearly of a Movements class:

[i]mmediately the pupils leave their work and place themselves in rows, and at a sign from the Magician they go through various movements resembling dances. The Magician's assistant moves up and down and corrects their postures and movements. These 'sacred dances' are considered to be one of the principal subjects of study in all esoteric school of the East, both in ancient times and at the present day. The movements of which these dances consist have a double purpose; they express and contain a certain knowledge and, at the same time, they serve as a method of attaining a harmonious state of being.

GURDJIEFF n.d.: 19

The Struggle of the Magicians reinforces this sense that the source of the teaching is "Islamic"; the heroine Zeinab, described as "of an Indo-Persian type," is the daughter of a wealthy khan and becomes crucial to a struggle between the White Magician and the Black Magician; at the ballet's conclusion, the White Magician is victorious and Zeinab and her suitor Gafar are united (Gurdjieff n.d., 8-9). The costume and set drawings have a strong "Arabian Nights" aesthetic, adding to the impression of an Islamic, or more properly Șüf, origin to Gurdjieff's teachings.

Yet it is surprisingly difficult to connect any of the music that Gurdjieff composed or Movements that he choreographed with particular ethnic or religious groups; Gert-Jan Blom claims to have identified the source of one tune, "Kurd Melody for Two Flutes" (Petsche 2015: 120). Similarly, there is one Movement where the words "Sharsche Varsche" are recited. Wim van Dullemen identified 


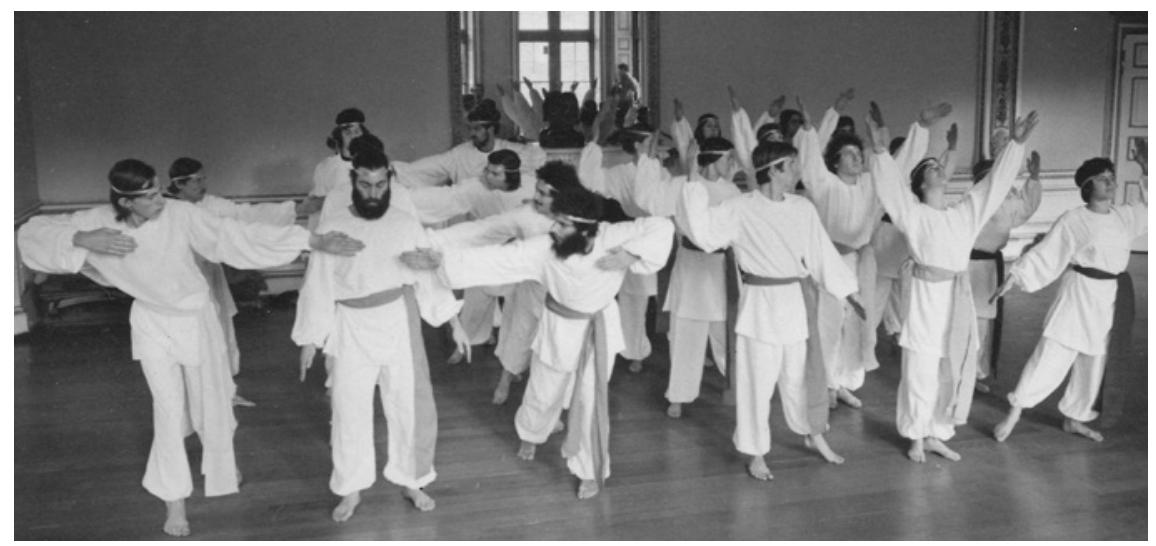

FIGURE 26.1 Enneagram Movement, Sherborne House, 1974

IMAGE COURTESY OF ANTHONY BLAKE

the source for this as a "ritual procession to honour the Holy Hussein, who fell at the battle of Kerbala, one of the twelve imams" referencing the death of Husayn, grandson of the Prophet Muhammad (van Dullemen 2014: 184). ${ }^{2}$ In Beelzebub's Tales Gurdjieff calls 'Saint Muhammad' "a genuine messenger of our Endlessness [God]” (Gurdjieff 1999 [1950]: 1091); Gurdjieff's books abound with comic tales of the Șūfi Mullah Nassr Eddin. Some Movements include

2 "In the distance, the muffled beat of a large drum could be heard, threatening as a warning from the Invisible. The dusty street glowed in the sun that shone directly above Schimran (the city in Persia where the author was located). The drum beat edged slowly closer and incessantly the cries 'Sha-ssé ... Wah-ssé' rang out: Shah Hussein ... Woe Hussein. The procession became visible and above the mass of people three large flags flapped. One on of the flag's Ali's name was written in large golden letters against a black velvet background. On the second, a large hand could be seen, the hand of the Prophet's daughter, Fatima, both blessing and threatening. On the third, so large that it almost obscured the view of the heavens above, just 'Hussein', the grandson of the prophet. The crowd proceeded slowly through the street with the penitents leading, dressed in black mourning attire but with bare backs and holding heavy chains in their hands that were whipped across their bleeding shoulders to the beat of the drum. Behind them walked a large semi-circle of broad-shouldered men, who took two rhythmic steps forward and one back. At each step, their chant 'Sha-ssé ... Wah-ssé' rose up and they hit their balled-up fists against their bare hairy chests. They were followed by-in white robes, like those of the dead, with deeply bowed heads-Martyrs, with shaven heads and long daggers in their hands, their faces closed off and dark as though they were looking into another world. 'Sha-ssé ... Wah-ssé. At each cry, the daggers flashed in the sunlight and fell across their shaven skulls, blood running over their (185) white robes. One of them fell to the ground and was quickly transported away by the crowd. I saw a beatific smile on his face" (van Dullemen 2014: 184-185). 
whirling, but there is evidence that Gurdjieff introduced this only after living in Istanbul in 1920.

\section{John G. Bennett, Subud, and Idries Shah}

Bennett met Gurdjieff and Ouspensky in Istanbul during his employment with British military intelligence in 1920-1921, and spent time at the Prieuré in 1923. He then was a pupil of Ouspensky and his wife, Sophia Grigorievna for many years. In 1946 Bennett established an Institute for the Comparative Study of History, Philosophy and the Sciences, which acquired Coombe Springs, a large house at Kingston-Upon-Thames, Surrey (Coates 2013: 182). In 1948 Bennett returned to Paris and Gurdjieff, and was with Gurdjieff when he died in 1949. Sitting by Gurdjieff's body before the funeral, Bennett felt that Gurdjieff's "power remained and ... his work would continue" (Bennett 1973: 272). Bennett is unique among the early pupils in that he was interested both in locating the sources of Gurdjieff's teaching, and in the possibilities of other religions and spiritualities. In 1957 he became intrigued by Subud, an Indonesian spiritual group led by Muhammad Subuh Sumohadiwidjojo (known as Bapak"elder or father" - or Pak Subuh), who taught an exercise, the latihan kejiwaan (training of the soul), which Bennett introduced to Work students at Coombe Springs (Rawlinson 1997: 185).

Fascinatingly, Bennett's involvement with Subud was the earliest transmission of Pak Subuh's ideas to Europe. The name Subud is formed from three Indonesian words derived from Sanskrit; Susila (good-tempered), Budhi (enlightenment) and Dharma (law). Stephen Urlich describes the latihan, during which men and women are segregated, as "uninhibited and unrestrained emotional expression, in which 'contact' with Subud's deity is made" (Urlich 2005: 163). Given that Indonesia is a primarily Islamic country it is unsurprising that Pak Subuh denied that Subud was a new religion:

[i]t is also necessary to explain that Subud is neither a kind of religion nor a teaching, but is a spiritual experience awakened by the Power of God leading to spiritual reality free from the influence of the passions, desires and thinking. That is why in the spiritual training of Subud one really feels that one's inner self is no longer influenced by the passions, heart and mind, which means that in the latihan kejiwaan of Subud the inner feeling has truly been separated from their influence.

SUMOHADIWIDJOJo n.d. 
Bennett then converted to Catholicism in 1961, the year that he went to India to consult "an Indian sage, Shivapuri Baba" (Rawlinson 1997:185). A break with Pak Subuh ensued in 1962. Thus, Bennett was a quintessential seeker and at various times had been a pupil of Ouspensky, Gurdjieff, Jeanne de Salzmann, Henriette Lannes, all in the Work tradition, and Pak Subuh, Abdullah Daghestani, Emin Chikou, the Maharishi Mahesh Yogi, and Shivapuri Baba outside the Work.

At Coombe Springs Bennett and his pupils built the Djameechoonatra, a structure based on the Enneagram. Its purpose was as a venue for performances of the Movements, and it evoked the Study House at the Prieuré (Coates 2013: 182). This was completed in 1965, but was destroyed the next year, after Bennett gave Coombe Springs to the soi-disant Șüfi teacher Idries Shah who sold it to property developers (Pittman 2012: 107). James Moore is scathing in his assessment of the relationship between Bennett and Shah. Bennett

became persuaded that Shah had come direct from Gurdjieff's 'Sarmoung Monastery' with a 'Declaration of the People of The Tradition'; how Shah pressed Bennett ('The caravan is about to set out') to give him Coombe Springs outright; how Bennett agonized, and in January 1966 complied; how Shah promptly repudiated Bennett, and sold the establishment for 100,000 [British pounds]; how Coombe Springs with its sub-Goetheanum Djamichunatra passed under the bulldozers; how Shah with the proceeds founded the Society for Organising Unified Research in Cultural Education (SOURCE) and the Society for the Understanding of the Foundation of Ideas (SUFI) and established himself at Langton House, Langton Green, near Tunbridge Wells_-all this defies both précis and belief, but is ... recorded in Bennett's autobiography Witness.

MOORE 1986: 4-6

Bennett had broken with de Salzmann in 1953, and he became one of the most creative and productive teachers of Gurdjieff's ideas. After the loss of Coombe Springs, Bennett began the International Academy for Continuous Education, at Sherborne House in Gloucestershire, in 1971 (Blake 2017: 168-170).

He designed a "year-long course ... utilizing Gurdjieffian techniques and ideas alongside material from other sources" (Coates 2013: 183). He was convinced that whirling dervishes practicing $z i k r$ at the Șúfi samác (spiritual concert) was identical to the self-remembering exercise of Gurdjieff, and he had made the acquaintance of Shaykh Abdullah Daghestani, the leader of the Naqshbandī Order in 1955 (Pittman 2012: 125). Later at Sherborne and at Claymont Court, Șüfism became core, with regular zikr and teaching sessions by 


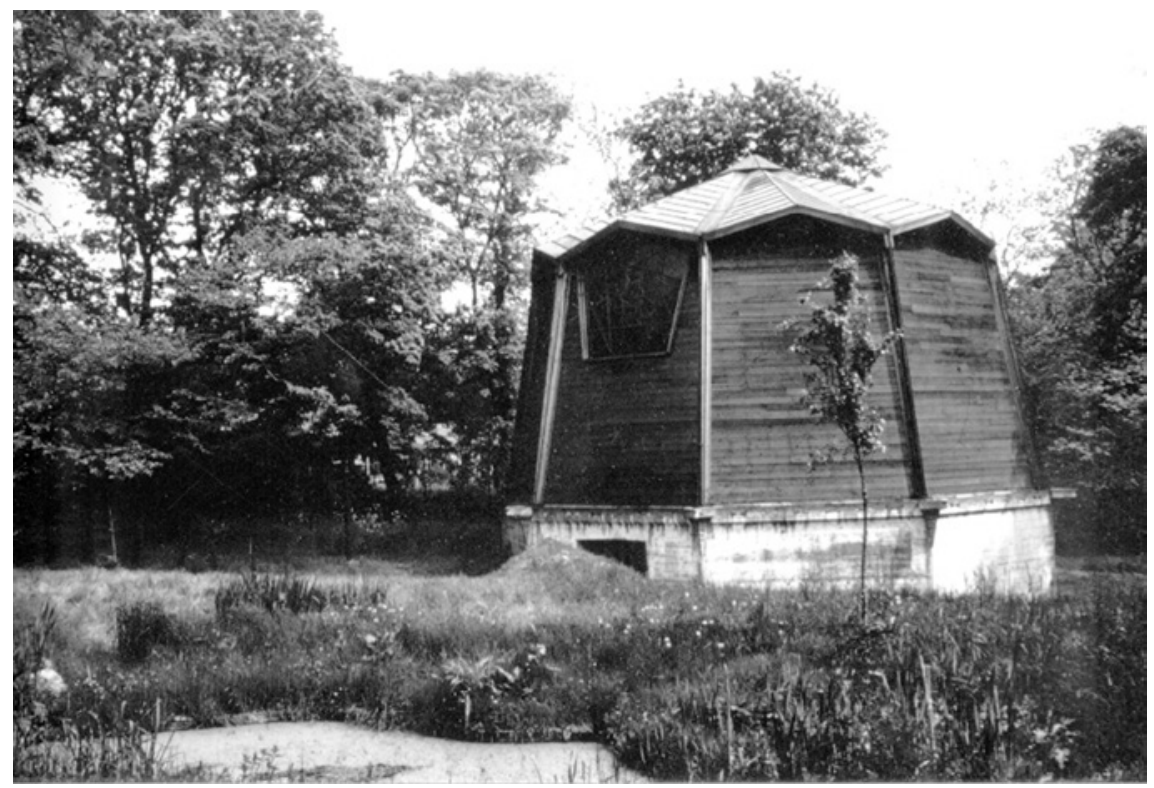

FIGURE 26.2 The Djameechoonatra, Coombe Springs, c. 1965 IMAGE COURTESY OF ANTHONY BLAKE

Șūfi leaders. Bennett bought Claymont Court in West Virginia in October 1974, just before his death in December. He wanted Claymont to host the Claymont Society for Continuous Education. Claymont Court was meant to house people living together in a self-sustaining agricultural community. Sedgwick notes that under Pierre Elliot (1914-2005), a teacher in the Bennett tradition, Șūfis including Reshad Feild (1938-2016), Muzaffer Ozak (1916-1985), and Süleyman Loras (1904-1985), who initiated Elliot as a Mevlevi shaykh (Sedgwick 2019: 133), taught at Claymont. The courses at Claymont Court ended in the 1980s, but it continues to be a site of "significant exchanges with a number of teachers and groups representing a wide variety of spiritual traditions and practices" (Pittman 2012: 211).

The involvement that Bennett had with various Șūfi groups and especially with Shah and his pupils had some long-term results that have proved problematic with regard to the academic study of Gurdjieff and his teachings. In 1966 a writer using the name 'Rafael Lefort' published a short book entitled The Teachers of Gurdjieff, which clearly emanated from the circle of Idries Shah and his elder brother Omar Ali-Shah, also a popular leader of Naqshbandī Șūfi groups in the West. This purported to be a series of interviews with 'authentic' Șüfi masters in Iran, Iraq, Turkey, Syria and a range of other countries, presented as those from whom Gurdjieff's ideas were derived, or (less diplomatically) 
stolen. ${ }^{3}$ Lefort claimed that Hakim Abdul Qader in Adana taught Jurjizada (Gurdjieff) weaving, at which he was "an attentive pupil" (Lefort 2008 [1966]: 12). Controversially, he alleged that Sheik Daud Yusuf in Kerbala (and sundry other figures he posited taught Gurdjieff) firmly dismissed Gurdjieff's teaching, saying "Gurdjieff is dead ... Gurdjieff passed his authority to none. His message died with him" (Lefort 2008: 28). ${ }^{4}$ While such criticism was unlikely to trouble Work members, it is clear that an attack on Gurdjieff's authority to teach was being mounted on the grounds of "tradition." Thus, the polemical tone of Ali-Shah is unmistakable:

Gurdjieff ... had been passed from Master to Master and he had most certainly assimilated various techniques, terms of reference, music, movement and other things; but he was not mandated to teach, and this is a very fundamental, important and crucial factor ... The amount of ... damage which was caused and is still being caused by Gurdjieff and his followers can be measured only in terms of human suffering and pain. All the more reprehensible from our point of view is that, after the death of Gurdjieff, Madame de Salzmann took over, to be subsequently followed by her son and one of the other dancing bears, and they knew what they were teaching was not real.

ALI-SHAH 1994: 223-226

It is interesting that Șüfis in the Shah lineage make such concerted attempts to attack Gurdjieff, when the Work itself (apart from Bennett's lineage) has not claimed Șūism as its root tradition or emphasised Șūfi influences at all.

The scholarly literature on Gurdjieff, which is relatively limited, contains efforts like Anna T. Challenger's Philosophy and Art in Gurdjieff's Beelzebub: A Modern Sufi Odyssey, an interesting book which nevertheless uncritically accepts the Bennett view that "the Sufi origins of his [Gurdjieff's] teachings were unmistakable for anyone who had studied both', consequently we may move back and forth with ease between Șūfism and Gurdjieff without

3 It is interesting that Lefort (1966) was taken seriously by many authors, including Theosophist Paul Johnson, whose Madame Blavatsky: 'The Veiled Years'. Light from Gurdjieff or Sufism? (1987), argued that "Since modern Sufis are claiming that Gurdjieff was trained in Sufic schools for a mission to the West, an examination of the possibility that H.P.B. was also indebted to Sufis is in order" (1987: 8).

4 This attitude was shared by Gary Chicoine (b. 1942) who, as "Rishi Dada Narayana" sent a letter to Bennett's Institute at Sherborne in August 1977 (Rawlinson 1997: 203). He presented himself as a teacher of Gurdjieff's original source and asserted, "The entire Gurdjieff Path as away in itself is truly defunct" (Thompson 1995: 549). 
a need for re-orientation" (Challenger 2002: 12). Harry T. Hunt's admirable attempt to situate Gurdjieff in the context of modern secular mysticism also states confidently,

What is clear is that Gurdjieff's final system contains a set of practices largely derived from Sufism, with a more Western psychology of the multiplicity of ordinary personality, all synthesized within an original version of Gnosticism and an attendant highly technical alchemy of alchemy of inner experience.

HUNT 2003: 227

Sedgwick, in studies of modern Șüfism in the West, has drawn attention to the fact that in the 1930s, in addition to Gurdjieff, there were other teachers of 'Sufism' (variously defined) in the West, including Hazrat Inayat Khan, Frithjof Schuon, Rudolf von Sebottendorff, Meher Baba, and René Guénon (Sedgwick 2016: 413). Michael Pittman, the most insightful and scrupulous chronicler of the discourse of Șufism within and without the Gurdjieff tradition, offers a more cautious and nuanced account of mutual influence in the Bennett legacy, with due restraint about Gurdjieff's relations with and/or debt to Ṣufis and Șūfism (Pittman 2012, 2013).

The Enneagram, a term that combines the Greek ennea (nine) and grammos (drawn or written), is a nine-sided figure, usually shown as a triangle inside a circle (connecting points 9,3 , and 6 ), that features in the esoteric system of Gurdjieff and was first described by Ouspenky. Gurdjieff said that the Enneagram was "completely self-supporting and independent of other lines and it has been completely unknown up to the present time" (Ouspensky 2001: 286), but many different origins have been traced for the symbol (including Christian, Șūi, and Kabbalistic) (Webb 1980: 505-519). The numbers around the circle show the Law of Seven (this for Gurdjieff was the musical octave of seven fundamental notes and two "semitone" intervals, so nine points). The points representing the seven fundamental notes are therefore labelled do, re, mi and so on. The Law of Seven determines all processes in the universe, according to a pattern of seven unequal steps. Gurdjieff used the "seven-tone scale," consisting of two sets of larger intervals-do re mi and fa sol la ti-and two smaller intervals, between $m i$ and $f a$, and si and the do of the next octave (Ouspensky 2001: 124-126; Gurdjieff 1984: 187-189). Gurdjieff taught that in 


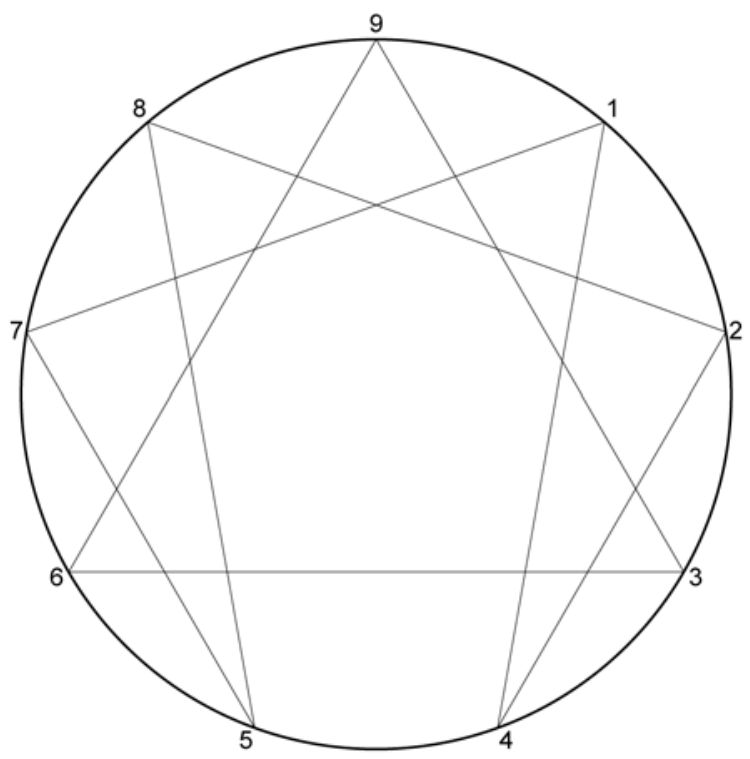

FIGURE 26.3

The Enneagram

IMAGE COURTESY OF

SEBASTIAAN VAN OYEN

all processes resistance is met at the smaller intervals, and a 'shock' is needed for processes to continue. The nine digits on the Enneagram do not show the Law of Seven with seven fundamental steps and two semitone or 'shock' steps exactly, as the distance between points is equal around the circumference of the circle, where intervals between tones and semitones vary. ${ }^{5}$ The unusual six-pointed shape inside the Enneagram is made by joining by straight lines the six numbers on the edge that make up the sequence of numbers that occur and repeat when 1 is divided by 7 (o.142857 repeated). The other points-9, 3 , and 6 - form an equilateral triangle symbolising the Law of Three, and points 3 and 6 correspond to the two shock intervals of the octave (Ouspensky 2oor: 290-291).

Gurdjieff claimed the Enneagram was a symbol of universal significance and enormous power:

the enneagram is a universal symbol. All knowledge can be included in the enneagram and with the help of the enneagram it can be interpreted. And in this connection only what a man is able to put into the enneagram does he actually know, that is, understand. What he cannot put into the enneagram he does not understand. For the man who is able to make use of it, the enneagram makes books and libraries entirely unnecessary.

5 Johanna Petsche, personal communication, 7 May 2013. 
Everything can be included and read in the enneagram. A man may be quite alone in the desert and he can trace the enneagram in the sand and in it read the eternal laws of the universe. And every time he can learn something new, something he did not know before. If two men who have been in different schools meet, they will draw the enneagram and with its help they will be able at once to establish which of them knows more and which, consequently, stands upon which step, that is to say, which is the elder, which is the teacher and which the pupil. The enneagram is the fundamental hieroglyph of a universal language which has as many different meanings as there are levels of men.

OUSPENSKY 2OO1: 294

This passage makes comprehensible the stern criticisms that 'orthodox' Gurdjieff groups make of unorthodox (but Gurdjieff-inspired) applications of the Enneagram, and those uses by non-initiated teachers who have never been part of the Work. The power claimed for the Enneagram by Gurdjieff explains why faithful followers believe that its misuse is dangerous. The Enneagram is a tool for analysing an individual's psychological condition (from the Greek psyche, soul) and his/her resultant spiritual status.

Gurdjieff also claimed that the Enneagram embodied "objective knowledge," a significant claim in the Work context:

[t]he symbols that were used to transmit ideas belonging to objective knowledge included diagrams of the fundamental laws of the universe and they not only transmitted the knowledge itself but showed also the way to it ... The fundamental laws of triads and octaves penetrate everything and should be studied simultaneously both in the world and in man. But in relation to himself man is a nearer and a more accessible object of study ... in striving towards a knowledge of the universe, man should begin with the study of himself and with the realization of the fundamental laws within him ... The transmission of the meaning of symbols to a man who has not reached an understanding of them in himself is impossible.

OUSPENSKY 2001: 280-281

Thus the Enneagram is a truly esoteric symbol; uninitiated humans without the necessary preparation to understand its meaning cannot apprehend its significance. This statement also links the diagnostic Enneagram which can identify a person's spiritual level with the developmental Enneagram that plots the course of spiritual progress that a person might go on to make. Further, the 
Enneagram is also a map of the microcosm-macrocosm relationship between the human and the universe.

James Webb, a non-Gurdjieffian, argued that the genealogy of the Enneagram lay in the Kabbalistic Sephiroth, by way of the Ars Magna ("The Great Art," c. 1305-1308) of Ramon Lull (c. 1232-1315), and the Arithmologia (1665) of Athanasius Kircher (1601-1680) (Webb 1980: 505-519). Biographer and Work member Moore rejects this, claiming the Enneagram "was intrinsic and peculiar to Gurdjieff's system, and unpromulgated before him" (Moore 2004 [1987]: 2). Sophia Wellbeloved has observed that that the turning nature of Gurdjieff's "Enneagram" Movements may suggest Dervish and Șūfi origins for the symbol (2003: 66), but offers no evidence to demonstrate this possible affinity. The Bolivian Oscar Ichazo, founder of the Arica School, rejected the alleged Șūfi origins of the Enneagram: "I know Șüfism extensively—I've practiced traditional zikr, prayer, meditation - and I know realized Șūfi sheiks. It is not part of their theoretical framework. They couldn't care less about the Enneagon [Enneagram]" (Patterson 1998: 24). Helen Palmer and Don Richard Riso (19462012), among other contemporary popularisers of the Enneagram of personality, continue to trumpet its 'Șūfi' origins. The neo-Ṣūfi A.H. Almaas has developed a method called the "Diamond Approach," in which "ancient wisdom" is integrated with depth psychology, and which uses the Enneagram, in a version derived from the Chilean Claudio Naranjo, who had been a pupil of Ichazo (Almaas 1998). Sedgwick has noted that in what he calls the "Enneagram movement" now largely ignores Süfism, with the exception of Iranian-American Laleh (b. Mary, 1938) Baktiar, who has affinities with both Frithjof Schuon's Traditionalist Șūfi order, the Maryamiyya and the Ni'matullāhī order of Javād Nūrbaksh (Sedgwick 2019: 141-142), and sundry other groups.

\section{6}

\section{Conclusion}

This chapter has demonstrated that, while there are Șüfi motifs and ideas that feature in the teachings of Gurdjieff, it is manifestly the case that Gurdjieff was not a Șūi and did not teach Șūfism. The discourse of Gurdjieff and Șūfism largely was the result of John Bennett's quest for the origins of Gurdjieff's system, which was complicated (and perhaps compromised) by his identification of Gurdjieff's "self-remembering" with $z i k r$, the remembrance of the names of Allāh (Bennett 1973: 219). Bennett's problematic relationship with both Muhammad Subuh Sumohadiwidjojo and Subud, and Idries Shah and the particular Western form of Naqshbandī Șūism he was associated with, add further layers of complexity to the story. However, other teachers in the 
Gurdjieff tradition have interpreted his teaching according to other templates (Christianity in the case of Maurice Nicoll, and with Hindu overtones in the later years of Jeanne de Salzmann, for example).

Scholars including Michael Pittman and Mark Sedgwick have traced the links that Șufism had with Gurdjieff himself and that his followers, loosely defined, have developed. The time in Constantinople in 1920-1921, when Gurdjieff and Ouspensky were both teaching and John Bennett made their acquaintance, is of particular importance, and the memories of time spent in the tekkes watching whirling dervishes have influenced the presentation of the Work as Șüfi-inspired (Pittman 2016:41). Pittman has researched figures including Ahmet Kayhan (1898-1988) and Jelaluddin Loras, who founded the Mevlevi Order of America in 1980 and taught at Claymont Court from 1978 (Pittman 2016: 46). These links involve mutual influence between the United States and Turkey, the Work and Șūfism, and friendships between Loras and Fourth Way teacher Pierre Elliot, for example, and also Reshad Feild (b. Richard Timothy, 1934-2016) (Sorgenfrei 2013: 114-117). Sedgwick has chronicled interactions between the Work and Șüfism in Latin America, covering figures including Rodney Collin (1909-1956), a pupil of Ouspensky who brought the Fourth Way to Mexico, Ichazo and Naranjo (discussed above), and also "[a] similar group in the Dominican Republic, the Gurdjieff Dominican Group directed by by José Reyes (born 1942) ... [which] retains on occasional emphasis on Șūfism" (Sedgwick 2018: 15). Reyes and Elliot were friends; Reyes went to Claymont and Elliot to the Dominican Republic, which explains the group's Șūfi features.

Those elements of Gurdjieff's teaching that have been claimed to be Șufi, such as the Stop Exercise, the Movements, and the Enneagram, when carefully examined are found to be not specifically Șūfi at all. ${ }^{6}$ Gurdjieff was a teacher who wore masks and played roles, and these masks and roles varied from pupil to pupil. Yet one continuous and never-repudiated thread in the Work was its pretension to unite the wisdom of the East and the West. In 1923, when he was becoming established in Paris, Gurdjieff spoke with Professor Denis Saurat, Director of the French Institute in London. He said:

6 There is another important project to be undertaken, to chronicle and analyse the difficult, one could say hostile, relationship between Gurdjieff and his pupils, and his younger contemporary, the Traditionalist and Șūfi René Guénon (1886-1951) and his pupils. Traditionalists have a very negative view of Gurdjieff; Whitall N. Perry, for example, says of the Stop Exercise that it "is a far remove from the ritual cessation of movement practised in dances like those of the Mevlevi Dervishes and the American Indians, where the flutes, the singing, and the drums unexpectedly stop on an explosion of sound between two instants, and the dance evaporates into the Void. It is the moment of death, the close of the cosmic cycle" (Perry 1978: 55). Perry's attitude to Gurdjieff is unambiguous; he is a "black magician" (Perry 1978: 74-75). 
I want to add the mystical spirit of the East to the scientific spirit of the West. The Oriental spirit is right, but only in its trends and general ideas. The Western spirit is right in its methods and techniques. Western methods alone are effective in history. I want to create a type of sage who will unite the spirit of the East with Western techniques.

SEYMOUR-SMITH 1998: $45^{1}$

The fictional memoir Meetings shows a young Gurdjieff who is fascinated by machinery and modern science, as much as Gurdjieff the seeker of truth was attached to ancient and perennial sources of wisdom. It remains to observe that if the Work is not Christian, not Șüf, not Buddhist, not Hindu, not Kabbalistic, it does not mean that it is suigeneris, or that it sprang fully-formed from Gurdjieff's intellect as Athena did from the head of Zeus. Recently Steven J. Sutcliffe made a case for Gurdjieff as a bricoleur, an indubitably inventive thinker, but one who was limited by the materials to hand, and not above "making it up" as he went along (Sutcliffe 2015: 117-137). Bricolage and invention are the next models to apply to Gurdjieff's teaching, to identify progress and change in the "system" and to map the historical development of one of the most innovative and interesting new religious groups (and new esoteric orders) in the modern West.

\section{References}

Ali-Shah, O. 1994. The Suf Tradition in the West. New York: Alif.

Almaas, A.H. 1998. Facets of Unity: The Enneagram of Holy Ideas. Berkeley, CA:Diamond Books.

Azize, J. 2010. "Solar Mysticism in Gurdjieff and Neoplatonism." Crossroads. 5:1, 18-26.

Azize, J. 2012. "Gurdjieff's Sacred Dances and Movements." In C.M. Cusack and

A. Norman eds, Handbook of New Religions and Cultural Production. Leiden and Boston: Brill, 297-330.

Barber, X.T. 1986. "Four Interpretations of Mevlevi Dervish Dance, 1920-1929." Dance Chronicle. 9:3, 328-355.

Bennett, J.G. 1973. Gurdjieff: Making a New World. New York: Harper Colophon Books.

Blake, A. 2017. "The Fourth Way: A Hazardous Path (Part 2)." Literature \& Aesthetics. $27: 2,167-222$.

Brenner, L. 1972. "Review Article. Separate Realities: A Review of the Literature on Sufism." The International Journal of African Historical Studies. 5:4, 637-658.

Challenger, A.T. 2002. Philosophy and Art in Gurdjieff's Beelzebub: A Modern Sufi Odyssey. Amsterdam and New York: Rodopi. 
Coates, C. 2013. “How Many Arks Does It Take?" In T. Miller ed., Spiritual and Visionary Communities: Out to Save the World. Farnham and Burlington, VT: Ashgate, 176-189.

Cusack, C.M. 2017. "The Contemporary Context of Gurdjieff's Movements." Religion and the Arts. 21:1-2, 96-122.

Geels, A. 1997. Subud and the Javanese Mystical Tradition. Richmond, UK: Curzon Press.

Gordon, M. 1978. "Gurdjieff's Movements Demonstrations: The Theatre of the Miraculous." The Drama Review. 22:2, 33-44.

Gurdjieff, G.I. 1999 [1950]. Beelzebub's Tales to His Grandson. London and New York: Penguin Arkana.

Gurdjieff, G.I. 1984 [1973]. Views From the Real World: Early Talks in Moscow, Essentuki, Tiflis, Berlin, London, Paris, New York, and Chicago As Recollected by His Pupils. London and New York: Penguin Compass.

Gurdjieff, G.I. 1985 [1963]. Meetings With Remarkable Men. London and New York: Penguin Arkana.

Gurdjieff, G.I. N.d. The Struggle of the Magicians: Scenario of the Ballet. Milton Keynes, UK: Lightning Source Ltd.

Hunt, H.T. 2003. Lives in Spirit: Precursors and Dilemmas of a Secular Western Mysticism. Albany, NY: State University of New York Press.

Johnson, P. 1987. Madame Blavatsky: 'The Veiled Years'. Light from Gurdjieff or Sufism? London: Theosophical History Centre.

Lefort, R. 2008 [1966]. The Teachers of Gurdjieff. Cambridge, MA: Malor Books.

Lilly, J.C. and J.E. Hart. 1975. "The Arica Training." In C.T. Tart ed., Transpersonal Psychologies. London: Routledge and Kegan Paul, 330-351.

Moore, J. 1986. “Neo-Sufism: The Case of Idries Shah." Religion Today. 3:3, 4-8.

Moore, J. 1991. Gurdjieff The Anatomy of a Myth: A Biography. Shaftesbury and Rockport: Element.

Moore, J. 1994a. “Katherine Mansfield and Gurdjieff's Sacred Dance." In R. Robinson ed., Katherine Mansfield: In From The Margin. Baton Rouge and London: Louisiana State University Press.

Moore, J. 1994b. “Moveable Feasts: The Gurdjieff Work." Religion Today. 9:2, 11-16.

Moore, J. 2004 [1987]. "The Enneagram: A Developmental Study." At www.Gurdjieff -Bibliography.com. Accessed 20/05/2015.

Ouspensky, P.D. Tertium Organum: The Third Canon of Thought, A Key to the Enigmas of the World. New York: Alfred A. Knopf.

Ouspensky, P.D. 2001 [1949]. In Search of the Miraculous: Fragments of an Unknown Teaching. New York and London: Harcourt Inc.

Patterson, W.P. 1998. Taking With the Left Hand: Enneagram Craze, People of the Bookmark, \& The Mouravieff 'Phenomenon'. Fairfax, CA: Arete Communications.

Perry, W.N. 1978. Gurdjieff in the Light of Tradition. Pates Manor, UK: Perennial Books Ltd. 
Petsche, J. 2015. Gurdjieff and Music: The Gurdjieff/de Hartmann Piano Music and Its Esoteric Significance. Leiden and Boston, MA: Brill.

Pittman, M.S. 2012. Classical Spirituality in Contemporary America: The Confluence and Contribution of G.I. Gurdjieff and Sufism. London and New York: Continuum.

Pittman, M.S. 2013. "Sufism and Beelzebub's Tales: Elements in Gurdjieff's Discourse on the Soul." In H. Hubbard et al., The Proceedings of the 18th International Humanities Conference: All And Everything 2013. All and Everything Conference, 211-230.

Pittman, M.S. 2016. "Through the Lens of Gurdjieff: Glimpses of Contemporary Sufism in Turkey." Fieldwork in Religion. 11:1, 36-52.

Rawlinson, A. 1997. The Book of Enlightened Masters: Western Teachers in Eastern Traditions. La Salle, IL: Open Court.

Sedgwick, M. 2010. "Sufis as Mythic Bearers of Esoteric Tradition." In A.B. Kilcher ed., Constructing Tradition: Means and Myths of Transmission in Western Esotericism. Leiden and Boston, MA: Brill, 413-426.

Sedgwick, M. 2016. Western Sufism: From the Abbasids to the New Age. Oxford: Oxford University Press.

Sedgwick, M. 2018. "Sufism in Latin America: A Preliminary Survey." Melancholia. 3, 4-34.

Sedgwick, M. 2019. "Sufism and the Gurdjieff Movement: Multiple Itineraries of Interaction." In J. Malik and S. Zarrabi-Zadeh eds, Sufism East and West: Mystical Islam and Cross-Cultural Exchange in the Modern World. Leiden and Boston, MA: Brill, 129-426.

Seymour-Smith, M. 1998. The 100 Most Influential Books Ever Written: A History of Thought from Ancient Times to Today. Secaucus, NJ: Citadel Press.

Sorgenfrei, S. 2013. American Dervish: Making Mevlevism in the United States of America. Unpublished PhD thesis, University of Gothenburg.

Sumohadiwidjojo, M.S. N.d. “The Basis and Aim of Subud." At http://www.subud.com/ english/english.basis.html. Accessed 25/05/2016.

Sutcliffe, S.J. 2015. "Gurdjieff as a Bricoleur: Understanding the 'Work' as a Bricolage." International Journal for the Study of New Religions. 6:2, 117-137.

Thompson, W.J. 1995. J.G. Bennett's Interpretation of the Teachings of G.I. Gurdjieff: A Study of Transmission in the Fourth Way. Unpublished PhD thesis, University of Lancaster.

Urlich, S.C. 2005. "Evaluating the Charismatic Group Subud: Javanese Mysticism in the West." Group Dynamics: Theory, Research, and Practice. 9:3, 161-172.

van Dullemen, W. 2014. Gurdjieff's Movements: The Pattern of All and Everything. Self-Published.

Webb, J.1980. The Harmonious Circle: The Lives and Work of G.I. Gurdjieff, P.D. Ouspensky and Their Followers. London: Thames and Hudson.

Wellbeloved, S. 2005 [2003]. Gurdjieff: The Key Concepts. London and New York: Routledge. 